\title{
Homeroom Teacher in University Craftsman Spirit Embodied in the Work Baosheng Guo ${ }^{1}$ and Hongying $\mathrm{Ji}^{2}$ \\ ${ }^{1}$ Beihua university student work place, Jilin Jilin 132013 \\ ${ }^{2}$ Beihua university economic management college, Jilin Jilin 132013 \\ 492171239@qq.com, 418470072@qq.com
}

Keywords: Homeroom Teacher; Cultivating Moral Character and Building People; Craftsman Spirit

\begin{abstract}
Class tutor system is an important driving force and effective means of colleges and universities to do a good job of cultivating moral character and building people, this article will use the method of literature analysis, questionnaire and so on, to explore homeroom teacher in students' academic guidance, study style construction and the important value of creative education. At the same time, combining the reality of ideological and political work and the homeroom teacher practical work situation, innovative ideas, to encourage and promote the inheritance and carry forward the spirit homeroom teacher, in the realization of cultivating people should play the role of basic task, help students grow up in an all-round way.
\end{abstract}

\section{Introduction}

Xi Jinping, general secretary in 2016 national conference on ideological and political work in colleges and universities highlights : College ideological and political work relations colleges and universities cultivate what kind of people, how to cultivate people and who cultivate people this fundamental question. It is important to cultivate people as the central link and carry out ideological and political work through the whole teaching process of education, realizing the whole process of educating people and educating people in all aspects, we have made efforts to create a new situation in the development of our country's higher education business. [1] Class tutor system is an important driving force and effective means of colleges and universities to do a good job of cultivating moral character and building people, Inheriting the spirit of craftsman in the work of cultivating people, will give special and crucial guidance and help to students' employment and entrepreneurship and study style.

\section{The Work Connotation and Value of Class Mentor}

The education dictionary defines the tutorial system as follows: The tutorial system is a kind of education system, the main characteristic is individual guidance, the direction is the student's study, life and ideological and moral aspect [2] .The homeroom teacher can complement the counselor and the head teacher team better and has a special role in the ideological and political work of college students.

The Homeroom Teachers Can Make Full Use of the Classroom Teaching Carrier and Enrich the Working Form of Cultivating People. Homeroom teacher is one of the work in various disciplines of professional teachers, can make use of different forms, with different carrier, give full play to the effective function of classroom teaching, through classroom teaching effectively cultivating people work carrier, implement multiple teaching position concentric accordant with strength development. [3]

The Teacher Can Make Full Use of Professional Learning Platform to Deepen the Work Connotation of Cultivating People. The homeroom teacher can teach the professional theory knowledge while setting up the student professional thought; while carrying out professional practice, we can cultivate the spirit of the student craftsman and establish the correct idea. The combination of the cultivating people and the professional learning, the combination of teaching and education, and the enrichment of the connotation, really make the cultivating people work and move. 


\section{The Spirit of Craftsman and the Value of Time}

On March 5, 2017, Li Keqiang, the prime minister in the national "two sessions" government work report points out, vigorously carry forward the spirit, culture, strengthen the craftsmen fulfill ethics and advocating excellence, cultivate numerous "craftsmen in China". [4]

Artisan Spirit. Spirit is derived from the ancient guild, analysis of art and craftsmanship differentiation of different (see below), for how can we look at the modern spirit of living space and lineage craftsmen to offer help.

Table 1 Analysis of Art and Craftsmanship

\begin{tabular}{|l|l|l|}
\hline Source & Art & \multicolumn{1}{|c|}{ Craftsmanship } \\
\hline Subjectivity & $\begin{array}{l}\text { Rely on genius for inspira- } \\
\text { tion }\end{array}$ & Rely on constant practice \\
\hline The main body feeling & Follow your heart & $\begin{array}{l}\text { Seek recognition from the commu- } \\
\text { nity }\end{array}$ \\
\hline Timeliness & Positive and painful & The sense of belonging \\
\hline Original & High is sudden & Change is slow \\
\hline Autonomy & $\begin{array}{l}\text { Low (to please the buyer, } \\
\text { also to face the situation that } \\
\text { the work is not understood) }\end{array}$ & $\begin{array}{l}\text { Low With authority as one (em- } \\
\text { bodied in the workshop master) }\end{array}$ \\
\hline Authority & $\begin{array}{l}\text { Short lived and silent (rely- } \\
\text { ing on tacit knowledge) }\end{array}$ & It comes from religion and ritual. \\
\hline
\end{tabular}

The Value of Craftsman Spirit. Spirit is popular occupation and work ethic of the concentrated reflection of professional spirit, to work for perfection is not only the quality of workers, is also a member of the national quality to work, especially the socialist core values of "professional" requirements. [5] The spirit of the contemporary Chinese craftsman should include serving the people heart and soul, loving the job, devoting, striving for excellence, and so on.

\section{The Teacher Should Have the Spirit of Craftsman in the Work of the University}

The class tutorial system should further improve the understanding of the mind, inherit the spirit of the craftsman, and embody the value of the teacher's work in the work of cultivating people.

To Be Guided by Thought, to Be Willing to Give, to Shape the Spirit of Work. MAO Zedong said, "Man is to have a little spirit, and the revolutionary spirit of the proletariat is to come from here." [6]The teachers of the class should "set a good position" and "be sure" in their minds to deepen their understanding of the significance of cultivating moral character and building people, the first in cultivating moral character, and shape the new spirit of work. Homeroom teacher is good for moving to product is, in spirit and personality to the student positive energy, enhance the influence of a teacher by worthy example, to reform and innovation way of thinking and practice to build a good relationship between teachers and students [7].

Improve the Ability of the Short Board, Keep Improving, and Improve the New Level of Work. Deng Xiaoping pointed out that "a school can cultivate qualified talents for socialist construction, the cultivation of comprehensive development, a worker with socialist consciousness of culture, the key lies in the teacher." [8] Teachers should guide students with their own ideas, knowledge and personality. To rely on rich professional knowledge and practical resource, take targeted measures and method, strive to cultivate the students' pioneering consciousness, innovative 
spirit and creative ability, and enhance the quality and ability of students to adapt to the society and the future development. [9]

Take Strong Measures, Innovate and Persist, and Enhance the New Energy of Working Mechanism. Establish a homeroom teacher, counselor collaborative education system is under the new situation to further strengthen and improve ideological and political education work, implement the important impetus to cultivate people. basic task and effective means. To comprehensively homeroom teacher and counselor team construction and clear class tutor job responsibilities, straighten out the class teacher and counselor education fundamentally and management responsibility division of labor, play a healthy and effective working together, with good working mechanism to promote the development of the teaching work, students work together, strengthen the working mechanism of the new energy. [10]

Class inheritance and carry forward the spirit mentor, cultivating people in colleges and universities work reflects the due value, will be beneficial to help students establish correct world outlook, the outlook on life and values, also will be conducive to further strengthen and improve the ideological and political work in colleges and universities, in the construction of style of study, innovation, entrepreneurship education play a important role, such as work for college students' growth, success, success lay a solid foundation.

\section{Acknowledgements}

Fund project: In 2017, the key subject of the 13th five-year plan of education science in Jilin province is "research on the construction of college counselors' workshop under the vision of craftsman spirit" (ZD17019).

About the author: Baosheng Guo, male ;student work at Beihua university, associate professor, mainly engaged in the research of college students' ideological and political education effect; Hongying Ji, school of economic management at Beihua university, associate professor, mainly engaged in undergraduate entrepreneurship education and guidance.

\section{References}

[1] Xi. The ideological and political work through the education teaching process Create a new situation, our country higher education enterprise development in the national colleges and universities ideological and political work conference speech [N]. People's Daily(In Chinese), 2016-12-09 (01).

[2] The education great dictionary (additions and coils) [Z]. Shanghai: Shanghai education, 1998:185.

[3] Y.B. Liu. Thoughts on the tutorial system of undergraduate classes in ordinary universities [J]. Journal of changchun education college, 2015 (2) : 117.

[4] K.Q. Li: to promote the spirit of craftsman to cultivate many "Chinese craftsmen".

[5] J. Li Contemporary value and cultivation path of craftsman spirit [J]. China professional technology education, 2016 (27) : 27-28.

[6] MAO. "MAO Zedong", volume 7, people's publishing house(In Chinese), 1999:162.

[7] L.F. Cheng . Research on the work of class mentors under the education vision of ideological politics [J]. Journal of Liaoning vocational college, 2015 (7) : 70-71.

[8] X.P. Deng, Deng Xiaoping, vol.2, people's press(In Chinese), 1994:108.

[9] Z. Yang The work mechanism of university teachers in the new situation [J]. Journal of Liaoning normal university (zhe), 2016 (2) : 128.

[10]C. Tan and X.Y. Li. The construction of a collaborative education system for college majors and counselors [J]. Science and technology information, 2016 (33) : 106-107. 